\title{
A WEAPONIZED COURT OF JUSTICE IN SCHREMS II
}

\author{
JEFFERY ATIK, ${ }^{*}$ XAVIER GROUSSOT ${ }^{\dagger}$
}

The U.S.-EU conflict over the application of the General Data Protection Regulation (GDPR) to U.S.-based digital platform companies is marked by a startling legal development: the insertion of a constitutional court squarely into the heart of the dispute. The engagement of the EU's top court the Court of Justice (CJEU) - in the Schrems I and Schrems II cases - has significantly inflamed the dispute. The CJEU has now twice struck down GDPR accommodations reached between the United States and the European Union. In doing so, the Court has rebuked both U.S. and EU officials. By transfiguring provisions of the GDPR with constitutional (that is, treaty-based) and buman rights values, the Court has placed out of reach any accommodation that does not involve significant reform of U.S. privacy and national security provisions. Heated trans-Atlantic disputes involving assertions of extraterritorial extensions of regulatory power is an inappropriate place for a constitutional court like the CJEU to throw its declarative weight around.

\section{INTRODUCTION}

In two succeeding negotiations - first the Safe Harbour, ${ }^{1}$ and then the Privacy Shield ${ }^{2}$ - U.S. and EU officials reached agreement that qualifying U.S.-based data processors - such as digital platforms Google and Facebook - would enjoy the protection of the GDPR adequacy determinations by compliance with these accommodations. And twice - in actions brought by the same complainant, Max Schrems ${ }^{3}$ - the CJEU struck down the Commission's underlying adequacy decisions, ${ }^{4}$ as well as other aspects of the accorded frameworks. The absence of deference by the Court to the EU institution charged with the conduct of external relations is surprising; that said, the Court's assertion of the prerogative of re-assessing determinations by

\footnotetext{
* Professor of Law and Jacob Becker Fellow, Loyola Law School - Los Angeles and Guest Professor of Civil Law, Faculty of Law, Lund University.

† Professor of European Union Law at the Faculty of Law, Lund University.

A preliminary version of this article was presented at the seminar The Consequences of Schrems II from Practical and Theoretical Perspectives sponsored by the Swedish Network for European Legal Studies and held at the Faculty of Law, Lund University on September 16, 2021. We are grateful for the research assistance of Robert Miller.

1 The Safe Harbour arrangements was the first mechanism permitting the export of personal data from the EU to the United States in compliance with the terms of the GDPR.

2 The Privacy Shield arrangements permitted lawful transfers of personal data from the EU to the United States for processing by U.S.-based companies certified to be in compliance with the Privacy Shield principles under U.S. law. ${ }_{3}^{3}$ Max Schrems brought a series of actions with the Irish Data Protection Authority challenging the Safe Harbour and Privacy Shield. The ultimate questions in these actions were referred to the CJEU.

4 The CJEU invalidated the Safe Harbour decision in 2015 in Case C-362/14 Maximillian Schrems v. Data Protection Commissioner (Schrems I) ECLI:EU:C:2015:650. The Safe Harbour regime was replaced by the Privacy Shield regime in August 2016. The Privacy Shield addressed some, but now all, of the defects identified by the CJEU in Schrems I. The CJEU invalidated the Privacy Shield regime decision on July 16, 2020 in Case C-311/18 Data Protection Commissioner v Facebook Ireland Ltd and Maximillian Schrems (Schrems II) ECLI:EU:C:2020:559.
} 
EU administrative officials is a settled matter of EU law, squarely within the competence of the CJEU. It is less clear whether the Court's invocation of human rights bases for rejecting the finding of adequacy should escape external scrutiny. In Schrems $T^{5}$ and even more emphatically in Schrems II, ${ }^{6}$ the Court strikes down accords with the United States on a basis that extends beyond mere non-conformance with the GDPR. The Court goes further - and adds EU constitutional (treaty-based) and human rights foundations to its rejection of the equivalency of the U.S. privacy / national security regimes. ${ }^{7}$ And the Court demonstrates that a constitutional court is a blunt instrument indeed to deploy in a sensitive and significant debate between the trans-Atlantic political, economic and legal great powers. The European court may be right - but it is not necessarily right - in its world view of what human rights demands in the field of personal data privacy, and an assertion that it is the last word for the entire trans-Atlantic data space is as surprising as it is unhelpful.

There is good reason to expect a constitutional court - when faced with a measure that is pointedly extraterritorial - to take into account the interests of external actors. And a constitutional court should be prudent in projecting its constitutional reach, which should be more circumscribed than the intended reach of an ordinary regulatory measure. But this essay is not concerned with the correctness of the CJEU's decision, as an interpretive, constitutional or public international law matter. We rather make the call for awareness. The CJEU has either been insensitive to the concerns of American subjects and others with regard to the GDPR - or it has deliberately ignored them - by projecting a 'Europe First' response to the admittedly worrisome use of personal data by U.S.-based digital platforms.

The striking down of a moderating instrument resulting from negotiations between U.S. and EU officials - the Privacy Shield in Schrems II - by the Court can be described as a belligerent use of law - if not open 'lawfare. ${ }^{8}$ The EU was certainly free to act as a first mover in promulgating the GDPR; there had been no sign of legislative movement to be found within the halls of the U.S. Congress. But as a first mover, the EU legislative bodies did not intend to deprive the United States of room for manoeuvre. Indeed, the legislative/administrative/diplomatic acts of concording first the Safe Harbour and later the Privacy Shield demonstrate the desire of the Commission (at least) to enter into accommodation with the United States in the field of digital privacy. Not so the Court.

By striking down the two accommodations, the Court transformed what might have been a stimulating first action in a regulatory field into a rigid, unyielding demand. To us it appears that it is the Court, in its holdings in Schrems I and Schrems II, that converted a situation of legal conflict into an instance of legal belligerency.

Regulatory conflict is marked by (1) resistance, (2) unsustainability, (3) application of legal force and (4) pressure for de-escalation. The presence of intentionality, inflexibility and targeting indicate the belligerent use of law, arguable a form of 'lawfare. ${ }^{9}$ For the moment, it is difficult

5 Schrems I (n 4).

6 Schrems II (n 4).

7 ibid paras 122 et seq, the CJEU extensively relying on Article 7, 8 and 47 of the EU Charter.

${ }^{8}$ See infra the discussion in sections 3.3. and 4.

9 ibid. 
to measure the resistance to the CJEU's latest move: Schrems II. American and European lawyers are hard at work to identify small and large reforms to the American privacy regime that could satisfy the Court's (rather vague) demand for equivalency of protection. General non-compliance by U.S. actors with the full force demands of GDPR is not easily observed.

The GDPR conflict with the United States is unusual in that the CJEU figures prominently. Indeed, there may not have been a dispute (at least at this point) had the Court not intervened. The entry on scene of a constitutional court - like the CJEU - may under certain conditions constitute an act of legal belligerency. Whether a court is an instrument of lawfare depends in part on what the court does - and in part on what it is capable of doing.

When a court elevates a contested regulatory feature into an incontestable constitutional norm it commits an act of extraterritorial aggression. And this, it appears, the CJEU has done in striking down successively the two EU-U.S. resolutions in Schrems I and Schrems II.

\section{INTERNAL AND EXTERNAL VIEWS OF SCHREMS II}

GDPR contained a conciliatory feature - a permissive equivalency test - that could have served to adjust the regulation's external effects. And through a series of adjustments (and smoke and mirrors as well), the United States was able to persuade the Commission that the U.S. privacy regime provided adequate (though not identical) protections to EU data subjects when compared to those provided them by the GDPR. ${ }^{10}$

An adequacy determination could be many things. It could simply be a political expediency, whereby real conflict is swept away, providing comfort to both domestic and foreign constituencies. Equivalency can be a technical exercise, where resort to different means is assessed to determine if they achieve the same desired end of legal protection. In both these cases, the first and ordinary equivalency determination is generally undertaken by an administrative (that is, executive) agency. Equivalency determinations are not ordinarily suited to judicial resolution.

\subsection{SUSPICIOUS MINDS: EXTRATERRITORIALITY CONFLICT IN THE TRANS- ATLANTIC SPACE}

Courts have generally played minor roles in past trans-Atlantic conflicts involving the asserted improper extraterritorial reach of one party's regulation. During the antitrust conflicts of the 1960s and 1970s, courts were given the unpleasant task of managing clawback actions that were intended to neutralize the undesired extensions of effects-based jurisdiction. One observed little judicial enthusiasm on either side of the Atlantic for the instrumental resort to courts as battlegrounds over whether U.S. Sherman Act actions should or should not reach London-based cartels. Rather, courts understood that comity, as a general principle, required a degree of legal flexibility.

\footnotetext{
${ }^{10}$ Commission Implementing Decision (EU) 2016/1250 of 12 July 2016 pursuant to Directive 95/46/EC of the European Parliament and of the Council on the adequacy of the protection provided by the EU-U.S. Privacy Shield [2016] OJ L207/1.
} 
In the 1996 Helms-Burton controversy, where the United States threatened to expose European operators of confiscated property in Cuba to harsh compensation claims by elements of the U.S.-based Cuban diaspora, ${ }^{11}$ courts played no role at all. Helms-Burton had a safeguard built in - no legal actions under the Act were available so long as the President maintained a waiver. ${ }^{12}$ The U.S. legal system was implicated by Helms-Burton: the essence of the threat was unleashing private litigants against European corporate interests in order to bolster adhesion to the U.S. economic embargo against Cuba. (In an act of cynical manipulation, Helms-Burton filled the heads of U.S. citizen granddaughters and grandsons of the pre-revolutionary Cuban moneyed class with delusions of recovering significant wealth from those European companies.) The Europeans resisted Helms-Burton, politically and legislatively. An EU regulation implemented a claw-back should any Helms-Burton recovery take effect. But to date, HelmsBurton has not been tested by any court, U.S., European or Canadian, given the gapless continuity of presidential waivers.

It has been a relentless feature of extraterritoriality conflicts that the offending party asserts serious internal effects of external behaviour that justify reach. And so it has been the case with the Europeans in justifying the reach of the GDPR. The entry into effect of the GDPR had been well anticipated by both American and European interests. The somewhat sophist notion of 'export' of personal data made clear the EU's intention to subject American digital giants to EU rules. Yet hard-wired into the GDPR was a mechanism to relieve some of the inevitable pressure: the GDPR, by its terms, exempted from the 'export' prohibition any data processing that occurred in countries with data protections 'equivalent' to those found in the GDPR. ${ }^{13}$

\subsection{IDENTIFYING DISCRETION WITHIN SCHREMS II - INTERNAL VIEW}

We begin with a brief recapitulation of the internal view of the Schrems II decision - that is, an account that would be adopted by an EU constitutional lawyer. We look at the sources of law utilized by the CJEU and at the Court's exercise of authority in reaching its judgment. We will stipulate that the Court reached a 'correct' decision when viewed from this internal perspective. There is little to gain from contesting the Court's judgment as a matter of EU law. Rather we will explore whether there existed a range of alternative determinations that the Court could have reached that would have avoided the resultant trans-Atlantic conflict. That is, we will describe (as well as we are able) the field of discretion open to the Court. We conclude regardless of the correctness of the CJEU's judgment as a matter of EU law - the Court was not compelled to rule as it did and so could have adopted a more conciliatory stance.

\footnotetext{
11 See U.S.C ch 69 A $₫ 6021$ et seq.

12 See for development, Antonella Troia, 'The Helms-Burton Controversy: An Examination of Arguments that the Cuban Liberty and Democratic Solidarity (LIBERTAD) Act of 1996 Violates US Obligations Under NAFTA' (1997) 23 Brooklyn Journal of International law 603.

${ }^{13}$ European Commission, 'Adequacy decisions: How the EU determines if a non-EU country has an adequate level of data protection’ <https://ec.europa.eu/info/law/law-topic/data-protection/international-dimensiondata-protection/adequacy-decisions_en $>$ accessed 11 December 2021.
} 
The terms of the regulation - the GDPR - are of course binding on the Court. Absent conflict between the GDPR and some higher order EU law (such as a conflicting treaty norm), the Court is obliged to give effect to GDPR's terms. Processing of personal data requires either consent ${ }^{14}$ or compliance with GDPR provisions. Any data transfer - internal or export - must comply with the terms of GDPR Article $6 .{ }^{15}$ Some transfers must comply with the stricter requirements of GDPR Article 9.

But the relevant term underlying the Court's holding striking down the Privacy Shield arrangements with the United States in Schrems II involves the 'adequacy' determination found in GDPR Article 45. ${ }^{16}$ Article 45(1) provides:

A transfer of personal data to a third country or an international organisation may take place where the Commission has decided that the third country, a territory or one or more specified sectors within that third country, or the international organisation in question ensures an adequate level of protection. Such a transfer shall not require any specific authorisation.

GDPR further outlines both substantive and procedural considerations that underlie any adequacy determination. Among the examined substantive features of the export country's legal system (here, the U.S. legal system) are its adherence to the rule of law, human rights and fundamental freedoms as well as any counterpart legislation, regulation or case-law. Among the procedural considerations is the existence of 'independent supervisory authorities ${ }^{17}$ charged with enforcing data privacy rules.

Again, our project in this section is to discuss zones of discretion available to the CJEU. The first involves the review the Court was compelled to apply to an extant determination by the Commission that the United States did satisfy the 'adequate level of protection' required by GDPR Article 45. It is beyond the scope of this essay to take a deep dive into the deference the Court could or should afford a Commission action either generally or in this specific instance. ${ }^{18}$ But we imagine that the Court had a sound legal basis - had it chosen to do so - to limit its review of the Commission's adequacy decision.

Further, on a searching review of the Commission's action, the Court faced terms endowed with substantial ambiguity, which created opportunity for the authoritative interpreter (here the Court). The Court was free to give meaning to terms such as 'adequate' or 'independent' (with regard to the third country supervisory authorities) as it saw fit - and in so doing effect the resultant consequences of the Court's (as opposed to the Commission's) meaning.

\footnotetext{
14 'Consent. General Data Protection Regulation (GDPR)' (Intersoft Consulting,) < https://gdprinfo.eu/issues/consent/> accessed 11 December 2021.

15 'Art. 6 GDPR - Lawfulness of Processing. General Data Protection Regulation (GDPR)' (Intersoft Consulting) <https://gdpr-info.eu/art-6-gdpr/> accessed 11 December 2021.

16 Schrems II (n 4) paras 168-169, para 177, paras 181-188 and paras 198-203.

17 Insert reference to Court's assessment of U.S. compliance with independent supervisory authorities requirement.

${ }^{18}$ See in general on discretion given to the European Commission, Damien Geradin and Nicolas Petit, 'Judicial Review in EU Competition Law: A Quantitative and Qualitative Assessment' (2010) TILEC Discussion Paper No 2011-008, and Joana Mendes, Executive Discretion and the Limits of EU Law (OUP 2019).
} 
But more than the resolution of ambiguity is demanded with regard to the adequacy decision of the Commission. The adequacy decision is a process and leads to a result. When the Court reviews the adequacy decision of the Commission, it goes beyond mere interpretation of a legislative term.

We further note the sources available (and utilized) by the CJEU in reaching its judgment in Schrems II. In addition to the provisions of Schrems II, the Court had direct access to treaty provisions, Charter provisions, and general principles in its review - and indirect access (as general principles) to the wider corpus of ultra-Charter international human rights law. ${ }^{19}$ This approach is common not only to the recent case law of the CJEU on the GDPR ${ }^{20}$ but also to the whole approach of the CJEU in the cases concerning digitalization in the processing of personal data such as Privacy Internationa ${ }^{1}$ and La Quadrature $d u$ Net. ${ }^{22}$ This also confirms the view that the CJEU has played a major role in shaping data protection in to a proper fundamental right. ${ }^{23}$ Moreover, GDPR Article 45 expressly directs an effectiveness evaluation of the rule of law, human rights and fundamental freedom within the United States. ${ }^{24}$

The demands of the 'rule of law' or 'human rights' or 'fundamental freedom' are fluid, to say the least. ${ }^{25}$ There can be no doubt that the CJEU is an authorized and respected juridical voice in contributing meaning to these categories of legal norms. It is precisely because the CJEU enjoys the status of a world-class articulator of these norms ${ }^{26}$ that it enjoys discretion in its application of these norms. Since Schrems I, the Court is keen to link the protection of EU Charter to the rule of law problematic defines as État de droit ${ }^{27}$ and thus propelling a substantive rule of law in the legal order of the European Union. ${ }^{28}$ We suggest that the Court could have found in its evaluation of the U.S. data privacy regime compliance with the GDPR's effectiveness mandate without betraying a cogent adherence to the rule of law, human rights and fundamental freedom. Here too was present discretion that could have been exercised in a different way.

19 Schrems II (n 4) and (n 8).

20 ibid.

${ }^{21}$ Case C-623/17 Privacy International v Secretary of State for Foreign and Commonwealth Affairs and Others (Privacy International) ECLI:EU:C:2020:790.

22 Joined Cases C-511/18, C-512/18 and C-520/18 La Quadrature du Net and Others v Premier ministre and Others (La Quadrature du Net) ECLI:EU:C:2020:791. See in this volume, for an assessment of the negative reaction of the French national supreme court to the CJEU answer, Araceli Turmo, 'National Security Concerns as an Exception to EU standards on Data Protection' (2021) 4(2) Nordic Journal of European Law, 86. According to her, 'The French Government had in fact encouraged the French supreme court to go down the same path in reaction to La Quadrature du Net, in order to preserve French regulatory provisions allowing the indiscriminate gathering and retention as well as relatively unrestricted access to this metadata by security and intelligence services'.

${ }^{23}$ Susanna Lindroos-Hovinheimo, Private Selves: Legal Personhood in European Privacy Protection (CUP 2021), 11.

24 Schrems II (n 4).

${ }^{25}$ Xavier Groussot and Gunnar Thor Petursson, 'Je t'aime moi non plus: Ten Years of Application of the EU Charter of Fundamental Rights' (2022) 59(1) CMLRev (forthcoming).

26 ibid.

27 Schrems I (n 4) para 95.

${ }^{28}$ See Paul Craig, 'Formal and Substantive Concepts of the Rule of Law: An Analytical Framework' [1997] Public Law 467, and Xavier Groussot and Johan Lindholm 'General Principles: Taking Rights Seriously and Waving the Rule-of-Law Stick in the European Union' in Katja Ziegler and others, Research Handbook on General Principles in EU law: Constructing Legal Orders in Europe (Edward Elgar 2022) (forthcoming). 
At this point, we cannot resist making a comparative comment. U.S. constitutional principles require courts - where they enjoy discretion - to exercise their discretion in a manner that supports both the determinations of the administrative agencies they are reviewing (Chevron doctrine $)^{29}$ and in a manner consistent with international legal obligations (Charming Betsy doctrine $)^{30}$ that arguably would have included the Privacy Shield arrangements between the EU and the United States.

In concluding our remarks here on the internal correctness of the Court's judgment in Schrems II, the telling inquiry is not whether the Court was correct in the judgment it reached but rather would the Court have been correct in reaching an alternative disposition of the matter. If an alternative judgment were available to the Court that would have preserved the Privacy Shield, it then becomes a matter of external scrutiny whether the Court should have acted differently. We suggest that the Court had not been legally compelled to reach the conclusion it reached in Schrems II - without in our so doing asserting any internal legal error in its judgment.

\subsection{IDENTIFYING DISCRETION WITHIN SCHREMS II - EXTERNAL VIEW}

We restate our view that the CJEU is presumptively correct in its holding in Schrems II as a matter of internal EU law. This would be true, of course, of any judgment of the CJEU with regard to a question of EU law and results from the primacy of the Court within the EU legal system. The inherent correctness of the CJEU in Schrems II does not, however, insulate it from critique or disregard from external vantages, at least with respect to definitions and applications involving those categories of norms that are located in shared legal space. It is open season for the Americans and others to challenge the Court's resort to rule of law, human rights law and fundamental freedoms, as the CJEU is far less privileged in these domains than it is within the EU law closure.

There are certainly many areas of rule of law or human rights or fundamental freedom analysis that have been fleshed out by courts and tribunals throughout the world. But within the specific domain of the protection of personal data, there is thin law at best. Indeed, the very best positive law in this field is the GDPR and other European legal initiatives. But Europe, as the sole or primary occupant of this specific legal domain, can hardly claim that its proprietary approaches deserve global (or universal) recognition as constituent features for human rights law. There is certainly a first mover advantage in many fields of international law, but Europe's pioneering foray into data privacy rights does not make the GDPR a de facto standard against other approaches (or non-approaches) adopted by other nations.

What then might international human rights law (or rule of law or fundamental freedoms) demand of the United States with regard to the protection of personal data? At the moment,

\footnotetext{
29 'If the intent of Congress is clear, that is the end of the matter; for the court, as well as the agency, must give effect to the unambiguously expressed intent of Congress...if the statute is silent or ambiguous with respect to the specific issue, the question for the court is whether the agency's answer is based on a permissible construction of the statute' - Chevron U.S.A. v. Natural Res. Def. Council, 467 U.S. 837, 104 S. Ct. 2778 (1984).

30 '[A]n act of Congress ought never to be construed to violate the laws of nations if any other possible construction remains' - Murray v. Schooner Charming Betsy, 6 U.S. 64 (1804).
} 
there is no recognition of any such obligation by the U.S. Congress. Not only is there no relevant legislation, there are no visible legislative proposals in the pipeline. A few states - notably California - have been inspired by Europe's GDPR to adopt state-level data protection regimes, but most states have been as silent as the federal government itself. It is of course harder to read Congressional inaction than action, but it appears that the current state of American law and practice is one of non-recognition of any obligation to protect interests in personal data. This may, of course, change.

There may, however, be a Trans-Atlantic view (in contrast to either the European regulatory or U.S. laissez-faire stances) that deserves recognition, and that is the law expressed by the now-discarded Privacy Shield! The United States, through the act of negotiating a framework for trans-Atlantic data traffic, implicitly conceded a good part of the GDPR's international legitimacy. This concession may have been driven more by the realities of power (think Brussels Effect $)^{31}$ than by recognition of the intrinsic legitimacy of the European policy choices. We assert that it would be easier to claim the Privacy Shield represented the stance of international human rights law than the unadulterated GDPR itself.

\section{LOCATING SCHREMS II ON THE SCALE OF BELLIGERENCY}

\subsection{THE CONFLICT / COORDINATION / COOPERATION SPECTRUM}

The GDPR conflict between the European Union and the United States is first a legal conflict. The field describing the multiple exercise of what international lawyers call prescriptive jurisdiction - the application of law to regulate the conduct of a legal person - is known as private international law in most legal systems, although common lawyers recognize the area with the more evocative name 'conflict of laws'. But the GDPR conflict is also an economic and perhaps cultural conflict. There is a strand of conflict of law classification that it considers a predicament to be 'no true conflict' where a legal subject can comply fully with the demands of one relevant legal system without violating the demands of the counterpart legal system.

The 'no true conflict' scenario includes the frequent situation where one state proscribes behaviour that the other state does not address. Using this test, GDPR presents 'no true conflict'. Roughly speaking the GDPR constrains the ability of Google or Facebook to export personal

\footnotetext{
31 See in general Anu Bradford, The Brussels Effect: How the European Union Rule the World (OUP 2020). In her book, she shows the great power of EU law to influence the regulation of legal standards outside Europe. Her main argument is that EU law made in Brussels can set the legal standard of protection worldwide in many law fields such as competition law, health law, consumer safety, data privacy and artificial intelligence. The 'Brussels Effect' reveals the EU's unique power to influence global corporations and set the rules of the game while acting alone what she calls a 'unilaterally regulatory globalization'. EU law, due to its regulatory and legal strength, acts here as a soft power. The situation is comparable to the so-called 'California Effect 'where the Californian environmental standards can influence the rest of the US legislation due to the strong market power of the State of California in the US federation'. According to Bradford, four conditions are necessary to ensure the effect: 1) the existence of a very large economic market with enforcement power 2) a regulatory capacity with a preference to enact stricter rules 3) specific areas/policies used as regulatory targets 4) the need of non-divisible legal standards for the companies. EU is seen as a soft power which can influence without coercion the world legal standards. This regulatory and legal expansion is clearly connected to the existence of the lex mercatoria.
} 
data from the EU for processing in the United States; the ordinary operation of these platforms involves the processing of personal data as that notion is defined in the GDPR. Google or Facebook could fully comply with the GDPR export limitations by desisting from any data export. By so doing, Google or Facebook would not violate any conflicting U.S.-based legal mandate. The problem of course is that Google and Facebook wish to export EU-based personal data. ${ }^{32}$ Regulatory conflicts can be resolved. There is a spectrum that runs from true conflict (where the legal subject is caught between conflicting demands) to complete elimination of conflict through cooperation, such as by resort to a mirror-image (uniform) rule or the construction of a common rule shared within a higher legal space superimposed on two otherwise independent sovereign regimes. A fully cooperative resolution may more closely match the regulatory imperatives of one state than the other. At one extreme, the 'cooperative' solution might be a complete capitulation of one state to the regulatory choices of the other.

\subsection{COOPERATION AND COORDINATION IN REGULATORY CONFLICTS}

There are a variety of cooperative techniques available to the EU and the United States to resolve the GDPR conflict. Notwithstanding Europe's assertion of a first-mover advantage in the field of the protection of personal data rights, the United States and Europe could work toward eliminating conflicts and inconsistencies in this area. This might take the form of harmonization, where both the United States and Europe would adjust their current regulatory positions according to a common design. Under certain conditions, regulatory convergence can arise spontaneously, gradually resolving past conflict, as occurred in the field of corporate payments to foreign public officials.

As a formal alternative, the EU and the United States could have elevated the protection of personal data to a bilateral, multilateral, or global instrument. A cooperative promotion of a global standard based on a common EU - U.S. position with regard to the protection of personal data would likely attract the adhesion of many other countries (although perhaps not China).

And finally, data protection may be an area ripe for what we have described elsewhere as 'trans-Atlantic bicameralism', ${ }^{33}$ where the first initiative in a particular regulatory space (here the GDPR) is understood to be a functional proposal, to be accepted, rejected or amended by the trans-Atlantic counterparty. The next move, under this modality, would be for the United States to enact legislation adopted some or all of the GDPR (as it sees fit), with any remaining conflict eliminated through a process of reconciliation. Europe then would amend GDPR accordingly.

Cooperation is not an inevitable result, of course. The first-mover advantage can yield enduring benefits to the state that occupies a vacant regulatory space that touches multiple jurisdictions. Having enacted GDPR earlier than the emergence of any other data privacy regime, the EU both occupied the field and set the standard for all states which follow. The GDPR was

\footnotetext{
32 See also many litigations of the CJEU concerning Google and Facebook. See, eg, recently the pending Case C329/20 Facebook Ireland, and Opinion of Advocate General de la Tour (ECLI:EU:C:2021:97) in this case concerning consumer protection and Article 80 GDPR.

33 Jeffery Atik and Xavier Groussot, 'The Draft EU AI Regulation: Strategic Bicameralism in the Shadow of China' (2021) 72 EU Law Live Weekend Edition 2.
} 
designed to be global standard - and its insistence of adequacy and equivalency were designed to puncture less robust protections.

Coordination is a regulatory state intermediate between cooperation and conflict, where the first-movant preserves adequate policy space for alternative approaches. Follow on actors can adopt a variety of approaches where coordination remains available. Yet this is not the case for the GDPR, other than in the solution where data processing is fragmented between intraEuropean and extra-European spaces.

\subsection{REGULATORY CONFLICT}

In its native state, the GDPR likely introduced a conflict with the United States. ${ }^{34}$ The CJEU's judgments in Schrems I and Schrems II have inflamed that conflict. We argue that law can be used belligerently. ${ }^{35}$ This is a notion that grows out of the lawfare tradition that identifies an instrumentalized resort to law in order to achieve extra-legal goals, including policy dominance in our view. ${ }^{36}$ Lawfare is a nascent (often contested) ${ }^{37}$ terminology that should in our view deserve more academic attention. ${ }^{38}$ The concept of lawfare fits the issue of regulatory conflicts revealed by the CJEU case law, ${ }^{39}$ where the EU court tests the adequate level of protection required by Article 45 of the Charter in light of the EU Charter. ${ }^{40}$ Schrems I and Schrems II constitute in fact litigations where there is no consensual issue available to solve the regulatory conflicts due to the extensive interpretation of the fundamental right enshrined in the EU

\footnotetext{
34 See Bradford (n 31).

35 David Kennedy, Of W ar and Law (Princeton University Press 2006). See also Orde F Kittrie, Lawfare: Law as a Weapon of War (OUP 2016); Congyan Cai, The Rise of China and International Law: Taking Chinese Exceptionalism Seriously (OUP 2019).

${ }^{36}$ Charles J Dunlap Jr., 'Does Lawfare Need and Apologia?’ (2010) 43 Case Western Reserve Journal of International Law 121. The term 'lawfare' is employed in the field of international law by US and Chinese scholars since the last two decades. And it has now been used for the very first time in Europe on the $15^{\text {th }}$ of June 2020 by a leading scholar in European Union external relation law and governance - see Steven Blockmans, 'Why Europe Should Harden Its Soft Power to Lawfare' (CEPS blog, 15 June 2020) < https://www.ceps.eu/why-europe-shouldharden-its-soft-power-to-lawfare/> accessed 11 December 2021.

${ }^{37}$ See Wouter G Werner, 'The Curious Career of Lawfare' (2010) 43 Case Western Reserve Journal of International Law 61. See also Leila Nadya Sadat and Jing Geng, 'On Legal Subterfuge and the So-Called "Lawfare' Debate" (2010) Case Western Reserve Journal of International Law 153. As put by them: 'There are many nuances to the term, though lawfare is generally defined as a tactic of war where the use of law replaces the use of weapons in the pursuit of a military objective. Lawfare proponents increasingly claim that adversaries of the United States are manipulating the rule of law to undermine democracy and national security'. See also Scott Horton, 'The Dangers of Lawfare' (2010) 43 Western Reserve Journal of International Law 163. For him, the term of lawfare is ideologically charged.

38 There is in our view a need to build strong theoretical/conceptual foundations of lawfare since it reveals the real nature of our time, a time of big politics. This is the zeitgeist of our time. See for a recent use of the concept of lawfare in the context of the backsliding of the rule of law in Europe, Jeffery Atik and Xavier Groussot, 'Constitutional attack or political feint? - Poland's resort to lawfare in Case K 3/21' (EU Law Live, 18 October 2021) < https:/ / eulawlive.com/op-ed-constitutional-attack-or-political-feint-polands-resort-to-lawfare-in-case-k3-21-by-jeffery-atik-and-xavier-groussot/> accessed 11 December 2021.

${ }^{39}$ See in Schrems II (n 4) paras 168-177.

40 Schrems II (n 4 and n 16).
} 
Charter, in particular the right to data protection as defined in Article 8 of the EU Charter. ${ }^{41}$ These litigations show, arguably, that there is no neutrality of the CJEU in assessing the (euro-)rights are issue. ${ }^{42}$

Extraterritorially effective law is peculiarly objectionable when the enacting state has power - and there can be no mistaking the exercise of European power in the GDPR controversy. (The general exercise of European regulatory power is popularly known as the 'Brussels Effect'). ${ }^{43}$ A powerful state can impose its legal power by adopting a law suited to its interests and projecting its effects outside its borders. This may be a fair characterization of what the EU has done with the GDPR even before its hardening by the CJEU in Schrems I and Schrems II.

Conflict results when one partner makes law and precludes the other from freely making alternative regulatory choices. There are several markers of regulatory conflict that we can observe. The first is resistance. There was observed resistance to the GDPR by U.S. interests long before the regulation came into effect. And it remains an open question how deep compliance by U.S. firms with GDPR may be in practice; non-compliance is after all a form of resistance. And the energetic response by U.S. officials in negotiating the Safe Harbour and Privacy Shield arrangements with an eye to denaturing the more ambitious features of the GDPR further signals an underlying resistance.

\section{A WEAPONIZED CJEU}

\subsection{THE BELLIGERENT USE OF LAW}

One of the given premises of this article is that the CJEU decided Schrems II correctly as a matter of European law. That is, the question it was called upon to answer by the referring Irish High Court was within its authority (competency) and that its answer (the judgment itself) was supported by appropriate source law, including its resort to Charter and other treaty provisions as well as relevant general principles, including fundamental freedoms and other human rights notions.

We have further asserted that the CJEU might have reached equally correct (but different) conclusions, consistent with EU law including its higher law, that would have better contributed to locating a cooperative solution to the legal conflict arising within the concurrent jurisdiction occupied by both the EU and the United States.

We now propose that the judgment of the CJEU in Schrems II constitutes a belligerent use of law. And to do this, we now need to explore what we see to constitute a belligerent use of law. We use this phrase - belligerent use of law - to invoke at least part of the 'lawfare' tradition

\footnotetext{
${ }^{41}$ See for development Larry Yackle, Regulatory Rights: Supreme Courts Activism, The Public Interest and the Making of Constitutional law (University of Chicago Press 2007). See also for contrasting the GDPR with the proposed EU Regulation on Artificial Intelligence, Atik and Groussot, 'The Draft EU AI Regulation' (n 33).

${ }^{42}$ Lindroos-Hovinheimo (n 23) 27. The author considers the impossibility of neutrality in the situation of balancing of rights.

${ }^{43}$ See Bradford (n 31).
} 
- which categorizes certain legal uses that are improperly instrumentalized to serve purposes beyond the ordinary objects of law. ${ }^{44}$ In our view, an extraterritorial conflict arising from the predicament of concurrent jurisdiction is ripe for this kind of abuse.

Law-making inevitably involves a projection of power by the law-making state. It is first and foremost an internal exercise of power over the subjects of that state. But it also, to a lesser or greater degree, constitute an assertion of power outside the Westphalian territorial bounds. ${ }^{45}$ International law tolerates the extension of a law's effect beyond the territorial limits of the imposing states under certain conditions. Comity, as an independent mediating principle, counsels moderation in any extraterritorial extension as well as consideration of the regulatory interests of any other state co-occupying a particular regulatory space. As such, there must be additional elements that constitute a particular exterritorial extension 'belligerent' to avoid the term simply serving as a pejorative equivalent.

Intention can and should play a role in defining when a use of extraterritorial law is properly described as belligerent. Extraterritorial effect is often an inadvertent feature of regulatory design, an unintended spillover. Or an extraterritorial reach is intended to eliminate or reduce simple evasion or circumvention by actors presumptively subject to the regulation. The mere fact of extraterritorial effect cannot, in itself, be fairly described as belligerent.

Where a state imposing a regulatory scheme with extraterritorial effect that it intends to serve as a global standard (as opposed to a mere territorial approach among alternate possible approaches) this changes. Imposing a particular regulatory design on others deprives those others from appraising the regulatory space and selecting alternate approaches. When this is done intentionally, the end result extends beyond maximizing the legal effectiveness of one's own regime. Intentionally imposing one's regulatory responses achieves political ends, not legal ends.

The second indicator of belligerency is inflexibility. An unwillingness to adjust the projected regulatory approach to the needs and concerns of others suggests the presence of an aggressive intent. As we will note in the next section, supporting particular legal choices on a country's constitutional vision necessarily produces inflexibility. The degree of flexibility may not be apparent - as cultivating an illusion of strong commitment to a regulatory approach may bring a strategic advantage. But removing an extraterritorial legal regime from one of ordinary law to one founded on constitutional principles produces real rigidity. It is very difficult for a state that uses constitutional justifications for its policy designs to alter those designs. In the case of Schrems II - again as we will argue below - it is the CJEU that transforms the demands of a piece of ordinary legislation - the GDPR - into an uncompromising constitutional demand.

A third indicator is targeting regulatory subjects that are located extraterritorially. If the regulatory targets are asymmetrically distributed, disregard of the regulatory choices of the cohabiting states is more problematic.

\footnotetext{
${ }^{44}$ See generally on the issue of instrumentalization of law, Brian Z Tamanaha, Law as a Means to an End: Threat to the Rule of Law (CUP 2006).

${ }^{45}$ For a discussion on power, see, eg, David Dyzenhaus, 'Lawyers for the Strongman' (aeon, 12 June 2020)

<https://aeon.co/essays/carl-schmitts-legal-theory-legitimises-the-rule-of-the-strongman> accessed 11

December 2021. The author discusses inter alia the use of law by lawyers like Carl Schmitt.
} 
Where these features are present - intention, inflexibility and targeting - extraterritorial extension of a regulatory program can be described as hostile or belligerent. Belligerency suggests a war-like state - but does not necessarily mean that the state which makes belligerent use of law is acting wrongfully. This ultimate consideration requires further inquiry as to whether the resort to the belligerent use is justified - and whether the belligerent use of law involves legitimate means - additional features that will be considered in the following sections of this article.

\subsection{A CONSTITUTIONAL COURT AS AN INSTRUMENT FOR TRANS-ATLANTIC REGULATORY CONFLICT}

The CJEU cannot be critiqued for responding to the reference in Max Schrems' case before the Irish authorities. ${ }^{46}$ Clearly the referring court required guidance from the CJEU to assess Mr. Schrems claim that the Regulation implementing the Privacy Shield arrangements with the United States were outside of the bounds of EU law. ${ }^{47}$ The Court was likely compelled to enter the fray. Yet the Court need not have acted as it did in reaching its judgment in Schrems II. As we argue in the prior section, there was ample discretionary space for the Court to have reached a differing result. And further, there was ample alternative grounds for the Court to have reached the same result it did.

There is an inherent escalation of an international legal conflict whenever a constitutional court enters play. And the escalation is significantly enhanced when a constitutional court rests its judgment on constitutional or international law grounds.

In Schrems II the Court was asked to review the adequacy decision of the Commission that supported the Privacy Shield and its implementation in EU law. ${ }^{48}$ Article 45 of the GDPR does dictate the Commission to consider the presence of the Rule of Law, observation of international human rights and the respect for fundamental freedoms. Yet the Court chooses to disregard the Commission's assessment of these and other factors in concluding that the United States provided 'adequate' protection to the data privacy concerns of EU citizens. ${ }^{49}$

We move now from what could have been to what happened in Schrems II. The CJEU inserted itself into the trans-Atlantic conflict over the asserted extraterritorial effects of the GDPR in Schrems II. ${ }^{50}$ In invalidating the Privacy Shield arrangements based on its assessment of the adequacy of data protections provided by the U.S. certified data processors on a mix of human rights and fundamental freedoms principles, the Court not only struck a blow for maintaining the European notion of data privacy, it locked the EU into a position from which few concessions could be made. ${ }^{51}$

\footnotetext{
46 See in this volume, for an in depth analysis of the national proceeding, Graham Butler, 'Lower Instance National Courts and Tribunals in Member States, and Their Judicial Dialogue With the Court of Justice of the European Union' (2021) 4(2) Nordic Journal of European Law, 19.

47 ibid.

${ }^{48}$ See Schrems II (n 4, n 7 and n 16).

49 ibid.

50 ibid.

51 ibid.
} 
Entry by a constitutional court and recourse by a court to constitutional and international law grounds for a determination rejecting an agreed solution to a conflict involving concurrent jurisdiction the court imposed rigidities that the executive arm (here the Commission) cannot easily relax. In so doing, the Court diminishes the prospect of any cooperative solution. Accommodation or coordination becomes more complex and costly to achieve. And an enduring conflict - with attendant suspicions, hostility and recriminations - is likely to result.

In Schrems II, the Court held that a key element of the Privacy Shield, resort to standard contract clauses, had to ensure data subjects a level of protection essentially equivalent to that provided by the GDPR and the EU Charter of Fundamental Rights. ${ }^{52}$ The GDPR is ordinary law, a regulation promulgated by the legislative/administrative organs of the EU, whereas the Charter is constitutional in rank. ${ }^{53}$

It is very difficult, if not impossible, to bargain with the CJEU. This is true for the U.S. side in any post-Schrems II negotiations. It is also true for the Commission who cannot suggest potential conciliatory approaches without again risking the embarrassment of having its work tossed out by the CJEU. Having inserted itself twice in the muddle and having declared that any resolution of the conflict must meet an uncertain constitutional evaluation, the Court has significantly limited the room for manoeuvre for the Commission (which is, of course, generally charged with the conduct of external affairs).

The United States now faces the EU as both an unreliable and inflexible adversary in reaching any accommodation of the GDPR's demands with regard to U.S.-based data processing. The Court's action - striking down prior agreements reached with the Commission - make it difficult to take the Commission's proposals (or concessions to U.S. proposals) seriously, even when tendered in good faith. And to the degree that Court has established - as it seems it has - that ultimate appraisal of U.S. data protections will be measured against Charter standards (with the CJEU the ultimate specifier of what those standards are) sharply reduces the space for compromise or conciliation.

\section{3 'JUST WAR' LIMITS ON THE BELLIGERENT USE OF LAW BY A CONSTITUTIONAL COURT}

We have made two principal assertions at this point. The first is that the Court could have minimized its effect on the U.S.-EU bargain, either from exercising its discretion to provide for a more cautious outcome, or - while preserving the outcome it reached - by basing its judgment on ordinary law (ie, GDPR) grounds as opposed to far more rigid constitutional (eg, Charter and human rights) grounds. The second assertion is that the Court has acted belligerently by intervening in the trans-Atlantic dialogue over the proper extraterritorial extension of EU regulatory policy and imposing a purely European judgment that did not take into account U.S. interests.

\footnotetext{
52 Schrems II (n 4).

${ }^{53}$ See the text of Article 6 TEU and Article 289 TFEU.
} 
We now address whether there should be limits on a constitutional court to propel its constitutional and human rights vision into a zone where comity is understood to play a role. We have termed the CJEU's role in the trans-Atlantic dispute over the proper scope of data protection belligerent. By this we intend to characterize the Court's action as aggressive and unilateral. In so doing we deliberately invoke at least some of the 'lawfare' literature that describes the improper use of law to achieve strategic outcomes. ${ }^{54}$

The CJEU's judgment in Scbrems II may contribute to achieving Europe's goal of converting what nominally is a European approach into the de facto global standard for the protection of personal data. Schrems II vaults the undiminished GDPR as an unavoidable constraint on any global actor in the digital space. And - if the effect of Schrems II is to make satisfaction of GDPR's adequacy requirement or the Charter's equivalency requirement elusive, the CJEU may have shut down the possibility of any export of EU-sourced personal data - a result that goes beyond the clear design of the GDPR (which anticipates the export of personal data under certain conditions).

We suggest that the law of war may provide limits to what the CJEU or any constitutional court might do, inspired by counterpart limits within the law of war tradition. ${ }^{55}$ Before doing so, we recall that scenarios involving concurrent jurisdiction - from the case of the Lotus onward require a comity analysis and not a bull-headed insistence by a court that its internal views dominate the interests of the counterparty. ${ }^{56}$

In its traditional structure, the law of war divides between jus ad bellum (which addresses the justness of engaging in war) and jus in bello (which sets the limits on just means in armed conflict). This is a useful model for exploring possible limits on lawfare conducted by a constitutional court such as the CJEU. Let us first engage in an exploration of the circumstances where resort to lawfare may be considered just.

In a regulatory conflict that arises between two states enjoying concurrent jurisdiction, the ordinary expectation would be a joint and cooperative search for an arrangement that satisfies in part the expectations of each. A peaceful outcome results from what is an essentially political (diplomatic, if you will) process, involving political institutions. Resolution of regulatory conflicts need not, and in most cases should not, feature the intrusion of a judicial body from one of the contesting parties. There are compelling reasons sourced in institutional competence, access to information and pragmatics that make judicial intervention undesirable.

Of course, there are sound justifications for the entry of a court where legal interests are disregarded. Again, whether the Commission disregarded the rights of EU citizens in their personal data is beyond our evaluation. But the internal legal conditions that legitimates a court's

\footnotetext{
${ }^{54}$ See Kennedy (n 35) and Kittrie (n 35). Kittrie considers that lawfare is traceable to Hugo Grotius and his book Mare Liberum, published in 1609. In this book, he argues that under 'the Law of Nations the sea is common to all', 'that through it the Dutch accomplished what their naval and military forces could not, and they thereby "solidified the concept of freedom of the seas". That was to the benefit of the Dutch Indian Companie, which financed Grotius research. Though history, many examples can be found where the law is strategically used to achieve 'security objectives'.

55 ibid.

56 The Case of the S.S. 'Lotus' (France v. Turkey), 7 Sept. 1927, PCIJ, Ser. A., No. 10, 1927. See for a discussion on cooperation, Wolfgang Friedmann, The Changing Structure of International Law (Columbia University Press 1964$), 63$.
} 
intrusion can simultaneously represent an aggressive wrecking of a political solution that inflicts harm on at least one party - and perhaps both.

And so a potential jus ad bellum norm would caution a constitutional court in an ongoing conflicted concurrent jurisdiction scenario to refrain from engaging what might be idiosyncratic principles (or idiosyncratic interpretation of principles) unless there was some justificatory threat from the rival jurisdiction. We are open to the possibility that this might in fact be the case regarding the protection of personal data given the evident disinterest in the U.S. Congress to engage the policy space. Much as self-defence is long understood to justify resort to war, so too might certain provocations (or perhaps regulatory irresponsibility) justify a constitutional court from asserting its values without regard to comity considerations.

A justified war cannot be fought without limits as to means. Jus in bello operates independently of jus ad bellum. Again, by analogy, even were the intervention by the CJEU in this dispute to be fully justified, it does not follow that the means the Court utilizes are necessarily justified.

Two notions dominate the law of war as to just means: discrimination and proportionality. Discrimination addresses the requirement that force be confined to lawful targets; in its negative form, discrimination requires that force not be directed as a broad category of protected targets of the adversary (civilians, hospitals, combatants hors combat, etc.). A norm of discrimination in a 'lawfare' context might require recognition of certain core values (the U.S. Second Amendment, perhaps, to make a grotesque example) even when those values are not shared in the constitutional or fundamental freedom tradition of the intervening court. But there is little here to suggest that the CJEU was striking any core value of the United State in denying effect to the Privacy Shield. ${ }^{57}$

Proportionality, as an analogue concept, may have more purchase in the case of lawfare. ${ }^{58}$ Proportionality here would involve a balancing of interests between the objective of the imposed law (here the protection of the interests of EU citizens sharing personal data) and the legitimate harm to U.S. interests. ${ }^{59}$ In principle, some weight should be given to the laissez-faire regulatory stance of the United States. It may reflect a considered policy judgment that is entitled to some regard. Merely securing the profits (or worse, dominant positions) of Google or Facebook is another matter. These palpable interests may not be entitled to legal protections (outside of, perhaps, the currently moribund W'TO regime).

\footnotetext{
${ }^{57}$ See Schrems II (n 4).

58 See in this volume, Ester Herlin-Karnell, 'EU Data Protection and the Principle of Proportionality' (2021) 4(2) Nordic Journal of European Law, 66. According to her, 'many scholars have, of course, been interested in proportionality for a long time and there are very good reasons for such an extensive interest in the contours of proportionality'. In this article, we are linking the concept of proportionality to the nascent concept of lawfare. $59 \mathrm{ibid}$. According to her: 'The notion of proportionality is of course a golden rule in EU law. The principle of proportionality in EU law is taken to mean balancing the means and ends, in which the notion of appropriateness constitutes the golden thread for deciding on the desirability and need for EU action. Thus, proportionality is a classic in EU law and is one of the most crucial general principles, one which is used both as a sword and as a shield, usually in the context of to what degree the Member States could derogate from their EU law obligations. But it also constitutes one of the leading principles for deciding on whether EU legislative competence is warranted'.
} 
In EU law, the requirements of proportionality and discrimination can be viewed as ideologically loaded (non-neutral) concepts $^{60}$ as it resorts from a general analysis of their use through time in the CJEU case law; their use sometimes leading to broad discretion, sometimes not. ${ }^{61}$ Looking at their jurisprudential and historical application by the Luxembourg Court, litigations on proportionality and discrimination do often reflect the various policy approaches taken by the CJEU ${ }^{62}$ in a specific period of times that crystalize the understanding of the Court's activity as centralized/uniting or decentralized/diversifying. ${ }^{63}$ Whereas these two constitutional principles/requirements can both foster centralization and decentralization in the EU legal order, in recent years, perhaps due to the impact of the many crises in Europe, ${ }^{64}$ the CJEU case law exhibits strong elements of centralization and effectiveness that influence the level of discretion and tend to limit it in turn. ${ }^{65}$

To some degree, the requirements of discrimination and proportionality have a greater procedural effectiveness than substantive effectiveness. Battlefield liability results from command failures to consider the demands of discrimination or proportionality, rather than decisions that prove to have violative effects. Here the model would have asked the CJEU to reflect on whether the judgment reached in Schrems II unlawfully touched core interests of the United States (failure to discriminate) or whether its protection of European interests was outweighed to the burden the decision imposes on U.S. interests (proportionality). It may be that the CJEU's action could be defended as a substantive matter; its failure to fully reflect on effects on U.S. interests might condemn the judgment regardless. ${ }^{66}$

\section{CONCLUSION}

The CJEU, in Schrems II, could have taken a more conciliatory stance. It likely had the discretion to avoid striking down the Privacy Shield arrangements. And - even if it had been determined to invalidate the Privacy Shield, it could have confined the grounds to ordinary law. Instead, the CJEU acted as a magnificent constitutional court, exercising its authority over other EU institutions and resting its judgment importantly on Charter (that is, constitutional) grounds. In our view, the CJEU came crushingly into a conflict, as opposed to deftly avoid it. And within

\footnotetext{
${ }^{60}$ Joxerramon Bengoetxea, 'Rethinking EU Law in the Light of Pluralism and Practical Reason', in Miguel Maduro and others (eds), Transnational Law: Rethinking European Law and Legal Thinking (CUP, 2014) 145, 147. Bengoetxea refers to ideological coherence as being characterized by the values of the body politic as stated in and interpreted from the constitution.

${ }^{61}$ Gunnar Thor Petursson, The Proportionality Principle as a Tool for Disintegration in EU Law - of Balancing and Coherence in the Light of the Fundamental Freedoms (PhD Dissertation, Lund University 2014), see in particular ch 10 , 235 et seq.

${ }^{62}$ Xavier Groussot, General Principles of Community Law (Europa Law Publishing 2006), see ch 3, 126 et seq.

63 ibid.

${ }^{64}$ See generally on the issues of legality and crises, David Dyzenhaus, The Constitution of Law: Legality in a Time of Emergency (2nd edn, CUP 2013).

${ }^{65}$ Xavier Groussot and Anna Zemskova, 'The Rise of Procedural Rule of Law in the European Union - Historical and Normative Foundations' in Antonina Bakardjieva-Engelbrekt and others (eds), The Rule of Law in EU: Thirty Years after the Fall of the Berlin Wall (Hart Publishing 2021) 267.

${ }^{66}$ Schrems II (n 4).
} 
the conflict - an extraordinarily important conflict with the United States - the CJEU has acted belligerently.

Constitutional values of one party are ill-suited to satisfactorily resolve a legal conflict between two parties. A constitutional court, such as the CJEU - that sees its own law and not that of the counterparty to the conflict - makes reconciliation and resolution far less likely. Europe may 'win' this contest with the United States - and the CJEU's judgment in Schrems II may contribute to its policy success. But such a 'win' reflects the exercise of power more than law. 


\section{LIST OF REFERENCES}

Atik J and Groussot X, 'The Draft EU AI Regulation: Strategic Bicameralism in the Shadow of China' (2021) 72 EU Law Live Weekend Edition 2.

- _ ' 'Constitutional attack or political feint? -Poland's resort to lawfare in Case K 3/21' (EU Law Live, 18 October 2021) < https://eulawlive.com/op-ed-constitutional-attack-orpolitical-feint-polands-resort-to-lawfare-in-case-k-3-21-by-jeffery-atik-and-xavier-

groussot/> accessed 11 December 2021.

Bengoetxea J, 'Rethinking EU Law in the Light of Pluralism and Practical Reason' in Maduro M and others (eds), Transnational Law: Rethinking European Law and Legal Thinking (CUP 2014). DOI: https://doi.org/10.1017/cbo9781139236041.009

Blockmans S, 'Why Europe Should Harden Its Soft Power to Lawfare' (CEPS blog, 15 June 2020) <https://www.ceps.eu/why-europe-should-harden-its-soft-power-to-lawfare/> accessed 11 December 2021.

Bradford A, The Brussels Effect: How the European Union Rule the World (OUP 2020).

DOI: https://doi.org/10.1093/oso/9780190088583.001.0001

Butler G, 'Lower Instance National Courts and Tribunals in Member States, and their Judicial Dialogue with the Court of Justice of the European Union' (2021) 4(2) Nordic Journal of European Law 19.

Cai C, The Rise of China and International Law: Taking Chinese Exceptionalism Seriously (OUP 2019).

DOI: https://doi.org/10.1093/oso/9780190073602.001.0001

Chander A, 'Is Data Localization a Solution for Schrems II? Journal of International Economic Law', September 2020.

T Christakis, "Schrems III"? First Thoughts on the EDPB post-Schrems II Recommendations on International Data Transfers'. European Law Blog, November 2020.

Craig P, 'Formal and Substantive Concepts of the Rule of Law: An Analytical Framework' [1997] Public Law 467.

C Docksey, 'Schrems II and Individual Redress - Where There's a Will, There's a Way. Lawfare, October 13, 2020.

Dunlap C J, 'Does Lawfare Need and Apologia?’ (2010) 43 Case Western Reserve Journal of International Law 121. 
Dyzenhaus D, The Constitution of Law: Legality in a Time of Emergency (2nd edn, CUP 2013).

H Farrell and A Newman, 'Schrems II Offer an Opportunity - if the U.S. Wants to Take It'. Lawfare, July 28, 2020.

Friedmann W, The Changing Structure of International Law (Columbia University Press 1964).

Geradin D and Petit N, 'Judicial Review in EU Competition Law: A Quantitative and Qualitative Assessment' (2010) TILEC Discussion Paper No 2011-008.

DOI: https://doi.org/10.2139/ssrn.1698342

Groussot X and Lindholm J, 'General Principles: Taking Rights Seriously and Waving the Rule-of-Law Stick in the European Union' in Ziegler K and others, Research Handbook on General Principles in EU law: Constructing Legal Orders in Europe (Edward Elgar 2022) (forthcoming).

Groussot X and Petursson G T, 'Je t'aime moi non plus: Ten Years of Application of the EU Charter of Fundamental Rights' (2022) 59(1) CMLRev (forthcoming).

Groussot X and Zemskova A, 'The Rise of Procedural Rule of Law in the European Union - Historical and Normative Foundations' in Bakardjieva-Engelbrekt A and others (eds), The Rule of Law in EU: Thirty Years after the Fall of the Berlin Wall (Hart Publishing 2021).

Herlin-Karnell E, 'EU Data Protection and the Principle of Proportionality' (2021) 4(2) Nordic Journal of European Law 66.

Horton S, 'The Dangers of Lawfare' (2010) 43 Western Reserve Journal of International Law 163.

Kennedy D, $O f W$ ar and Law (Princeton University Press 2006).

Kittrie O F, Lawfare: Law as a Weapon of War (OUP 2016).

Lindroos-Hovinheimo S, Private Selves: Legal Personhood in European Privacy Protection (CUP 2021).

DOI: https://doi.org/10.1017/9781108781381

Mendes J, Executive Discretion and the Limits of EU Law (OUP 2019).

Petursson G T, The Proportionality Principle as a Tool for Disintegration in EU Law - of Balancing and Coherence in the Light of the Fundamental Freedoms (PhD Dissertation, Lund University 2014).

K Propp and P Swire, 'After Schrems II: A Proposal to Meet the Individual Redress Challenge'. Lawfare, August 13, 2020. 
Sadat L N and Geng J, 'On Legal Subterfuge and the So-Called "Lawfare” Debate' (2011) Case Western Reserve Journal of International Law 153.

Tamanaha B Z, Law as a Means to an End: Threat to the Rule of Law (CUP 2006). DOI: https://doi.org/10.1017/CBO9780511511073

Troia A, 'The Helms-Burton Controversy: An Examination of Arguments that the Cuban Liberty and Democratic Solidarity (LIBERTAD) Act of 1996 Violates US Obligations Under NAFTA' (1997) 23 Brooklyn Journal of International law 603.

Turmo A, 'National Security Concerns as an Exception to EU standards on Data Protection’4(2) Nordic Journal of European Law 86.

Werner W G, 'The Curious Career of Lawfare' (2010) 43 Case Western Reserve Journal of International Law 61.

Yackle L, Regulatory Rights: Supreme Courts Activism, The Public Interest and the Making of Constitutional law (University of Chicago Press 2007)

DOI: https://doi.org/10.7208/chicago/9780226944739.001.0001 